reading, as does Ruzicka's own obituary notice of Arthur Stoll ${ }^{2}$, which reveals much of Ruzicka himself as well as the subject of the memoir.

The writer thanks Professor O. Jeger and V. Prelog for their help in providing information and advice.

G. W. Kenner

1 A. Rev. Biochem. 43, 1-20 (1973).

2 Biogr. Mem. Fellows R. Soc. 18, 567-593 (1972),

\section{R. A. Morton}

Richard Alan Morton, Emeritus Professor of Biochemistry in The University of Liverpool, an outstanding British biochemist of his generation, died peacefully at his home on January 21 after a short illness; he was seventyseven. Born in Liverpool of Welsh parents, Professor Morton received his early education at Oulton School. After a short time in the Army he entered Liverpool University as an undergraduate in 1919 and, apart from a sabbatical year in the United States as Visiting Professor at Ohio State University in 1931, remained there until he retired in 1966. He graduated in chemistry and worked for his Ph.D. under Professor E. C. C. Baly, a pioneer in the application of spectroscopy to chemical problems; in 1924 he was appointed special lecturer in spectroscopy in the Chemistry Department where he remained until 1944, when, with great foresight, the University elected him Johnston Professor of Biochemistry. He held this chair, the first established chair of biochemistry in the UK, with great distinction for twenty-two years.

Professor Morton's early research work was concerned with relating the absorption spectra of chemical compounds to their structure and earned him the Royal Institute of Chemistry's Meldola Medal in 1930; later he pioneered the application of absorption spectroscopy to biology. This interest was first aroused in 1926 when he collaborated with Professor (later Sir Ian) Heilbron to show that an impurity in cholesterol isolated from cod liver oil and which exhibited absorption bands in the ultra violet region of the spectrum, was the compound which was converted by ultra violet irradiation into the anti-rachitic principle. These were the days before the structure of cholesterol was known, but the active compound eventually turned out to be 7-dehydrocholesterol. He then particularly concerned himself with vitamin $A$ which had two spectroscopic 'labels', an ultra violet absorption band $\left(\lambda_{\max } 328 \mathrm{~nm}\right)$ and the blue colour $\left(\lambda_{\max } 617 \mathrm{~nm}\right)$ which it gave on treatment in chloroform with a saturated chloroformic solution of antimony trichloride. Critical examination of the colour test led to his discovery of vitamin $\mathbf{A}_{2}$ which was found particularly in liver oils from fresh water fish. Again, thoughtful assessment of the absorption spectrum of 'retinene', the prosthetic group of the visual pigment rhodopsin, began work which led to his discovery in 1941-1942 that retinene was vitamin $\mathbf{A}$ aldehyde (retinal) and that the corresponding compound from porphyropsin from fresh water fish retinas was the aldehyde of vitamin $A_{2}$. These penetrating discoveries, which gave studies on the biochemistry of visual pigments a new impetus, resulted in Morton's election to the Fellowship of the Royal Society in 1950.

Other important investigations on vitamin A followed but the later stages of Professor Morton's research career saw two extremely important additional discoveries: the first was ubiquinone, discovered independently at the same time in the United States, and the second was the family of polyprenols. The impact of these discoveries on modern biochemistry was profound. The experts on electron transport could from then on carry out their experiments secure in the knowledge that in the case of ubiquinone they were dealing with a well characterised compound. Later work revealed the importance of polyprenols as carrier compounds particularly in cell wall biosynthesis. It gave Professor Morton great satisfaction in his retirement to follow the detailed elucidation of the biochemical significance of these compounds particularly when these developments were carried out by his old students.

During the second world war Morton was concerned with an investigation organised by The Accessory Food Factors Committee of the MRC to determine the vitamin A requirements of humans. The experiments were carried out on conscientious objectors who volunteered as experimental subjects. This stimulated a life-long interest in nutrition and although he never experimented further in nutrition he read deeply in the subject and made many thoughtful contributions to a number of nutritional working parties. In 1969 he was elected a member of The American Institute of Nutrition.

Under Professor Morton's sympathetic guidance the Department of Biochemistry at Liverpool prospered and his crowning achievement was to persuade the University to build the large new building in which the department is now housed. He developed an effective research school and a remarkably large number of his students now hold positions of high responsibility in places as far apart as India and Canada. Professor Morton's great gifts as a scientist and as a wise counsellor became well known outside the University early in his career and he was constantly in demand for professional committees; he served twice on the Council of the Royal Society, was Chairman of the Biochemical Society and was a member of many government committees. From 1963 to 1968 , he held the important position of Chairman of the Committee on Food Additives. He enjoyed writing and editing and was a member of the Editorial Board of the Biochemical Journal for seven years and Chairman of the Publications Board of the Royal Society 1961-1962.

$\mathrm{He}$ received honorary degrees from the University of Wales, Trinity College Dublin and The University of Coimbra, where his first research student became Rector. When he retired he was elected an Honorary Member of the Biochemical Society.

In retirement he continued to be as active as ever and he retained his fresh and enthusiastic approach to biochemistry right to the end. Indeed he had only just returned from an international symposium in India and at the time of his death was busy editing the proceedings. He spent a great deal of time on the work of the Oceanography and Fisheries Committee of the Natural Environment Research Council and in 1969 was Royal Society Visiting Professor at The Royal University of Malta. In spite of all this extramural activity he found time to complete two projects close to his heart: one was the History of the Biochemical Society (1911-1969) and the other a mammoth two volume new edition of his book Absorption spectra of Vitamins and Hormones last published in 1942.

In spite of his great achievements and international renown Professor Morton remained unassuming, friendly and approachable. His life shows that shrewdness and devotion to the demanding career of a scientist need not be divorced from kindness, gentleness and sympathy. His many friends and colleagues will remember Alan Morton as a distinguished scientist, wise in hîs judgement, humane in his outlook, whose long career brought lustre to biochemistry and to the University of Liverpool.

\section{T. W. Goodwin}

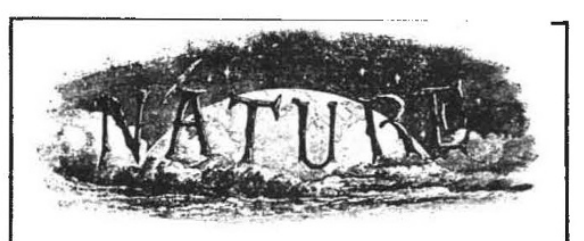

\section{A hundred years ago}

A bright violet meteor was observed at St Etienne on 11 March at two o'clock in the morning, in the southern part of the horizon. It was travelling with great velocity from west to east. No detonation was heard.

From Nature 15 March 22, 460; 1877 